Милан Д. Ђурић

Рачунарски факултет у Београду

Универзитет УниОН
069:004

https://doi.org/10.18485/melissa.2017.16.1.ch10

\title{
ТРАНСФОРМАЦИЈА МУЗЕЈА ДИГИТАЛИЗАЦИЈОМ
}

\section{Сажетак}

Дигитализација као незаобилазни фактор новог поретка утиче на све сфере живота савременог човека. Она утиче на промену већ постојећих навика али и исто тако одређује неке нове смернице сагледавања конзумације онога са чиме се сусрећемо у будућности што називамо модерно. Овде обично мислимо на продукте масовне индустрије, чија употреба исто тако утиче на стварање и у мануфактури, попут неког ауторског уметничког дела. Као потрошачи употребом геџита утичемо на њихов пласман на тржишту, односно порастом и самим тим они проналазе нове начине како да допру до нас на разноврсне начине, па их све чешће налазимо као додатак неког од апарата које користимо. Као један од таквих примера можемо узети паметни телефон. Његово коришћење утиче на развој компоненти које се употребљавају за његово функционисање до тог нивоа да је могуће применити их и на остале уређаје, па тако имамо паметне телевизоре, пегле, фрижидере и осталу многобројну потрошачку робу. Развојем технологије и масовном дигитализацијом потрошачи бивају упознати са могућностима геџита па врло лако упијају нове начине презентација њиховог функционисања.

Уметници у својим студијама истраживања и делима које изводе све чешће користе модерну технологију на инвентивне начине покушавајући да је имплементирају у свој рад. Истражују нове могућности као и спој нових технологија са традицијом. Користе дигитализацију представљајући своја дела, исто тако и туђа дела насталих у прошлости, али је доносе на потпуно нови начин путем нових технолошких могућности. Овај пример је конкретно присутан баш у модерним поствкама музеја чија поставка представља нека стара времена и заоставштину.

Рад Трансрормација музеја дигитализацијом се бави сагледавањем промена естетике музејских поставки у не тако далекој прошлости до данашњег дана утицајем модерних технологија. Бави се презентацијом примера на оствареним делима у музејским поставкама и сагледава модерне начине употребе решења презентације делова поставке путем пројекција, холограма, кинетик машином и уређајима за виртуелну стварност (VR).

Кључне речи: музеји, трансформација, дигитализација, виртуелна стварност, дигитална уметност, холограми. 


\section{0. Уводне напомене}

Дигитализација има утицај на све сфере живота савременог човека, тако што утиче на промену већ постојећих навика, а истовремено пружа и успоставља неке нове смернице сагледавања конзумације онога са чиме се сусрећемо у будућности и што називамо модерним. Као што се то констатује у литератури, „[...] свет постојећих медија је на различитим фронтовима, кроз процес дигитализације или компјутеризације, прошао кроз читав низ трансформација и дислоцирања [...]“ (Guga 2015: 31). Свакако, овај прелаз са аналогног на дигитално, учинио је и велику промену парадигме у савременој уметности. Оваква временско-просторна парадигма је довела до временско-просторне компресије просветитељства, модернизма и постмодернизма (Gržinić 1998: 17).

Мада идеја интерактивности и виртуалности у уметности нису нове, јер према литератури, ове је истраживао, између осталог и Марсел Дишан (фр. Marcel Duchamp), француски уметник и дадаиста, који је истраживао обртне и ротирајуће стаклене објекте у оквиру прецизне оптике (Paul 2008: 13), ипак, на интерактивност у уметности утичу и производи масовне индустрије. Истовремено, ми, као потрошачи, употребљавајући геџите утичемо и на њихов пласман на тржишту. Геџити које носимо на себи или са собом, свакако нису нова идеја, пошто су се, према историјату трансдисциплинарне дигиталне уметности (упореди: Adams, Gibson \& Müller 2008), носиве технологије, интерфејси, и проширени перформанси развијали још од 1880. године, па све до развоја данашњих рачунарских уређаја (Sjuve 2008: 301).

Ови геџити „проналазе“ нове начине како да допру до нас. Као један од таквих примера можемо узети паметни телефон (енг. smart phone). Његово коришћење утиче на развој компоненти које се употребљавају за његово функционисање до тог нивоа да је могуће применити их и на остале уређаје, па тако имамо паметне телевизоре, пегле, фрижидере и осталу многобројну потрошачку робу.

Иако уметници у својим делима, али и уметничким пројектима и истраживањима, све чешће користе модернутехнологију покушавајући да је имплементрају у свој рад на инвентивне начине, ипак истражују 
и могућност спајања нових технологија са традицијом. Уметници користе дигитализацију представљајући своја дела, али исто тако, путем дигитализације представљају и туђа дела настала током развоја уметности. Пошто они представљају дела на потпуно нови начин и то путем нових технолошких могућности, онда се свакако поставља питање трансписмености. Према литератури, концепт трансписмености дефинише се као могућност да се чита, пише и интерреагује на различитим платформама, са различитим алатима и медијима, као и комуникационим платформама (Thomas 2008: 101).

Овај рад сагледава промене естетике музејских поставки до данашњих дана под утицајем модерних технологија. Бави се извесним примерима музејских поставки и истовремено сагледава модерне начине употребе решења презентације делова поставке путем пројекција, холограма, кинетик машине и уређаја за виртуелну стварност (VR).

\section{0. Дефинисање релевантних појмова}

Према теоретичарима нових и дигиталних медија, кључни термини дискурса новомедијских дигиталних технологија су: дигиталност, интерактивност, хипертекстуалност, дисперзивност и виртуелност (види: Lister et al. 2009). Ауторка Гуга овим доминантним терминима придодаје концепте: урањање и телеприсуство (Guga 2015: 31).

У свом раду полазим од констатације, изнете у литератури, да смо у виртуелном свету заправо сведоци контекстуализације симбиозе високе технологије и човековог тела, што је генерисало услове за невероватно побољшање друштвене стварности (Gržinić 1998: 108). Овде бих дефинисао појмове који су релевантни у мом раду. За трансформацију музеја дигитализацијом релевантан концепт јесте телеприсуство (енг. telepresence), које је једним својим делом повезано са дигиталним технологијама, а којим се остварује присуство на различитим локацијама у исто време (Paul 2008: 154). Према овој ауторки, телеприсуство описује могућност способност да се буде присутан на удаљеној локацији, на пример, у чет соби на интернету, путем технолошких средстава (Paul 2008: 247). 
Релевантни појмови за ово истраживање и за дигитализацију музеја јесу и телероботика, холограми, кинетик машина, као и проширена стварност (енг. augmented reality). У литератури се проширена стварност дефинише као проширење окружења физичке стварности око нас путем рачунарски генерисаних елемената (Paul 2008: 247). Овако устројен виртуелни свет дигитализованих музеја подсећа на виртуелни свет у који води Дона Харавеј, а која у помоћ нуди малу машину за путовање која функционише као географска карта. Према Марини Гржинић, ова карта је заправо семиотички квадрат француског лингвисте и структуралисте Гремаса (фр. Greimas), а Харавејева задржава међусобно одвојена четири квадрата истражујући како се у њима одвијају локалне и глобалне борбе за значење (Gržinić 1998: 215).

У дигитализованом музеју као да постоји мапирање стварности на виртуелни свет, а све је попут неке позоришне игре, у којој, како то кажу неки теоретичари, не постоји ни неизбежност ни непредвидљив случај; ништа није у потпуности предвидљиво нити се тиме у потпуности може управљати, али ништа није ни потпуно непромењљиво ни неопозиво (Bauman 2005: 31).

У наредном делу погледаћемо музеје у светлу дигитализације, а укратко ћемо се осврнути на дигитализоване музеје, музеје са дигиталним поставкама и виртуелне музеје.

\section{0. Музеји и дигитализација}

Условно речено, у контексту музеја и дигитализације, може се направити следећа подела музеја у светлу нових медија и дигиталних медија, а то су:

1. Дигитализовани музеји

2. Музеји са дигиталним поставкама

3. Виртуелни музеји. 


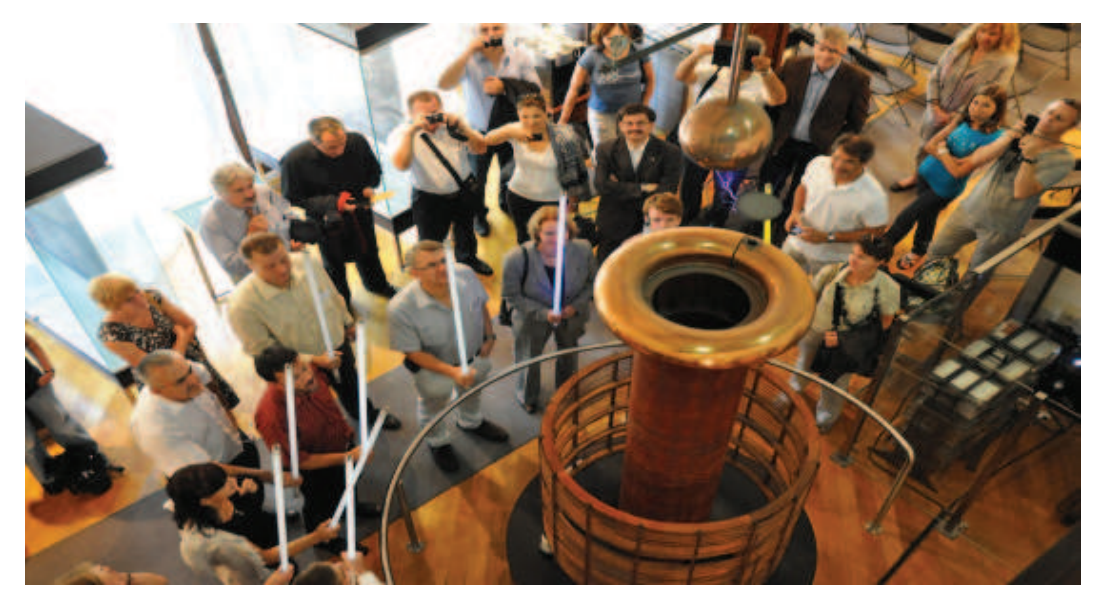

Слика 2.1.1. Перформативност и интерактивност на делу. Детаљ из Музеја Николе Тесле током јубиларне изложбе.

Као што се види на слици 2.1.1. могуће је сагледати перформативност и интерактивност на делу у савременим музејима који судигитализовани, попут Музеја Николе Тесле у Београду. У оквиру оваквих и сличних поставки, долази до преплитања класичних и савремених медија, а публика активно учествује, остварујући интеракцију, али и пружајући фидбек који може да се користи за даље унапређење музеја овог типа.

Дигиталне поставке обухватају више елемената, од којих су најважнији следећи елементи. Најпре су ту екранске пројекције које служе за приказ припремљеног материјала, а по својој природи су интерактивне. Затим су ту дигиталне светлосне пројекције (пројектори), које могу бити површинске и анимиране холограмске пројекције. Наравно, неизоставни елемент је и кинетик, а поменути релевантни концепт проширене стварности сагледава се комплементарно уз виртуелну стварност.

Музеји са дигиталним поставкама, могу се поделити на:

1. Музеје дигиталне уметности

2. Техничко-технолошке музеје

3. Архитектонске музеје 
Интерактивне поставке у савременим музејима нису више изузетак. Томе у прилог иде и констатација аутора Лева Мановича који помиње управо пример истраживања интерактивне инсталације у музеју објашњавајући интерфејс људи са софтвером (Manovich 2013: 2).

У следећим одељцима рада, осврнућу се на могуће трансформације музеја путем дигитализације, тако што ћу описати следећа три концепта, а то су: дигитализовани музеји, музеји са дигиталним поставкама и виртуелни музеји.

\subsection{1. Дигитализовани музеји}

Стари музеји су непромењеног садржаја али услед развоја технологије тај садржај се посматрачу презентује на другачији начин. Дигитализовани музеј може да подразумева нову визуелну презентацију непромењљивих ствари, уређаја, творевина или додатне дигиталне елементе који их ближе описују.

Примена технолошки доступних решења подразумева како технологију која потпомаже финални продукт попут новијих машина при изради графичких елемената који се користе у музеју, тако и самих постамената који су у дигиталној форми.

Дигитална форма презентације у овом типу музеја може бити заступљена као: екранска пројекција, дигитална светлосна пројекција, кинетик, пројектована стварност и виртуелна стварност.

Екранска пројекција подразумева презентацију садржаја који се директно односи на елемент који треба представити посматрачу, или индиректно у виду садржаја који ближе описује тај елемент. Презентација екрански пројектованог садржаја може бити у форми видеа или пак интерактивна, а овде се подразумева екран са посебним хардверским могућностима.

Дигиталне светлосне пројекције, за разлику од екранских, нису условљене физичком формом екрана. Оне садрже хардвер који је постављен упростору и путем снопа светла приказују сликучије димензије су условљене при самој поставци, а претходно су испланиране.

Кинетик је машина која програмирано интерреагује са посматрачем, односно учесником, а у служби ближег упознавања са тематским елементом или самом темом уопште. 
Пројектована стварност укључује додатно програмиране елементе, који се пројектују у односу на реално окружење, а ближе описују одређени садржај поставке музеја. Ово је битан концепт у оквиру дигитализације музеја, као и појам вирутелне стварности.

У литератури се констатује да је виртуелна стварност у блиском односу са рачунарским системима који граде и успостављају илузију ЗД околине (Gržinić 1998: 92). У дигитализованим музејима, виртуелна стварност може бити презентована у виду програма који пак, може бити интерактиван. Виртуелна стварност је постављена независно од реалних постамената, а ближе описује предмет или тему поставке дигитализованог музеја.

\subsection{2. Музеји са дигиталним поставкама}

Музеји са дигиталним поставкама за разлику од музеја где су такве поставке једино у служби ближег објашњавања елемената који су представљани и пре времена дигиталне ере, потпуно су испуњени искључиво дигитално представљаним елементима. Музеји дигиталне уметности су једни од значајнијих представника оваког вида уређења музеја.

\subsection{3. Виртуелни музеји}

Виртуелни музеји за разлику од дигитализованих и оних са потпуно дигиталним поставкама не подразумевају физички простор, већ се све одиграва у виртуелном окружењу, те стога нису условљени многим стварима за разлику од већ постојећих музеја у реалном простору. Ова чињеница указује да су они у константном развоју и неисцрпан су мотив за дигиталне уметнике, пошто представљају подрврсту музеја у којима је могућа потпуна контрола.

\section{0. Закључне напомене}

Трансформација музеја дигитализацијом је релевантна и суштинска у светлу нових медија, дигиталних медија и глобализације. 
Наравно и појавом минималне уметности (енг. minimal art), концептуалне уметности, и других видова уметности, теоретичари, попут Бодријара, истичу да је уметност присиљена да се учини минималном, а овај аутор експлицитно каже и да ће уметност у потпуности нестати претходно уступивши место великом вештачком музеју и распомамљеној реклами (Baudrillard 2001: 174).

У овом раду су сагледани различити аспекти могућности трансформације музеја дигитализацијом. У првом делу рада, дате су уводне напомене у вези са општим аспектима дигитализације, затим је указано на релевантност виртуалности и интерактивности. У наредном делу рада, дефинисао сам неке релевантне појмове. Централни део рада фокусира се на музеје и дигитализацију. Посебно се осврћем на дигитализоване музеје, затим, музеје са дигиталним поставкама, да бих онда укратко описао виртуелне музеје.

Идеја о трансформацији музеја дигитализацијом није нова, а преостаје да се у будућим истраживањима детаљније елаборира њихова улога у савременом глобализованом друштву.

\section{Литература}

Adams, Randy, Steve Gibson \& Stefan Müller (eds.). Transdisciplinary Digital Art: Sound, Vision and the New Screen. Berlin \& Heidelberg: Springer Verlag, 2008. Print.

Baudrillard, Jean. Simulacija i zbilja. Zagreb: Naklada Jesenski i Turk i Hrvatsko sociološko društvo, 2001. Print.

Bauman, Zygmunt. "From pilgrim to tourist - or a short history of identity", Teorija umetnosti 1 - Reader, eds. Nevena Daković \& Miško Šuvaković, 18-36. Beograd: Univerzitet umetnosti u Beogradu - Interdisciplinarne postdiplomske studije Univerziteta umetnosti, 2005. Print.

Gržinić, Marina. U redu za virtualni kruh. Zagreb: Meandar, 1998. Print.

Guga, Jelena. Digitalno ja: Kako smo postali binarni. Novi Sad: Centar za savremenu kulturu i komunikaciju_Artkult, 2015. Print.

Lister, Martin et al. New Media - A Critical Introduction. Second Edition. London \& New York: Routledge \& Taylor and Francis Group.

Manovich, Lev. Software Takes Command. New York: Bloomsbury, 2013. Print.

Paul, Christiane. Digital Art. Revised and Expanded Edition. New York: Thames and Hudson, 2008. Print. 
Sjuve, Eva. "Gesture, interfaces and other secrets of the stage", Transdisciplinary Digital Art: Sound, Vision and the New Screen, eds. Randy Adams, Steve Gibson \& Stefan Müller, 301-312. Berlin \& Heidelberg: Springer Verlag, 2008. Print.

Thomas, Sue. "Transliteracy and new media", Transdisciplinary Digital Art: Sound, Vision and the New Screen, eds. Randy Adams, Steve Gibson \& Stefan Müller, 101-109. Berlin \& Heidelberg: Springer Verlag, 2008. Print.

\author{
Milan D. Đurić \\ University Union in Belgrade \\ The Faculty of Computer Science
}

\title{
THE TRANSFORMATION OF MUSEUMS BY DIGITALIZATION
}

\begin{abstract}
Summary
Digitalization as an inevitable ingredient of the new social order influences all spheres of contemporary human life. Furthermore, it influences the changes of already existing habits, and also determines some new directions of observing the process of consuming those elements we encounter in future and that we call modern. Here, we usually refer to mass industry products, the usage of which also influences the manufacturing process of creation, such as a work of art. As consumers, by using gadgets we influence their market disposal, that is, their production increase thereby enabling them to find new and diverse ways to reach us. This is the reason why very often we find these gadgets as an additional part of the appliances we use. One such example can be a smart phone. Its utilization influences the development of components used for its functioning up to the level that they can be applied to other devices, and thus, we obtain smart TV sets, smart clothes iron, smart refrigerators, and other numerous consumer products. Technology development and general mass-digitalization make consumers aware of various possibilities of gadgets, and they accept and easily adapt to new ways of presenting their functionalities.

In their research studies and works of art, artists use modern technologies more often in inventive ways trying to implement them into their work. Moreover, artists explore new possibilities as well as the connection of new technology and tradition. They employ digitalization in order to present their work, the work of other artists from the
\end{abstract}


past, but in a totally new manner by new technological possibilities. In the concrete case, this example is present at modern exhibitions representing old times and heritage.

The research paper, Transformation of Museums by digitalization, focuses on observing the changes of museum exhibitions that occurred due to the influence of modern technology in the past that is not so distant up until these. Additionally, the paper presents the examples of finalized work within museum exhibitions and takes into account modern ways of utilizing the solution of presenting exhibition parts by means of projection, hologram, kinetic machine utilization, and devices for Virtual Reality (VR).

Key Words: Museums, Transformation, Digitalization, Virtual Reality, Digital Art, Holograms. 